\title{
Sacred Calendars: Calculation of the Hegira as a Historiographical Problem in Early Modern Spain
}

\author{
Fernando Rodríguez Mediano \\ ILC, CCHS-CSIC, Madrid
}

\begin{abstract}
This paper studies how Early Modern Spanish historians confronted the problem of calculating the equivalence between the Christian Era and the Hegira. Chronological polemics concerning the Hegira were deeply embedded in a major historiographical problem, namely the role Islam and al-Andalus played in the history of Spain. Besides the technical issues, chronology is one of the most important ways by which an Islamic Iberian past was integrated in a narrative about national history. Once Islam became a historical actor for Spanish and European historians, rather than just a religion to confront, very important questions were raised: were Arabic sources necessary for the writing of Spanish history? What were these sources, and what was their value? Since al-Andalus was connected with the more general problem of the relationship of ancient Spain with the Orient (and, specifically, with the Biblical Orient), the chronological argument became a major issue in reflections on the limits and possibilities of writing the sacred history of Spain.
\end{abstract}

\section{Keywords}

Chronology - Hegira - Spanish sacred history - Early Modern Spain

* English translation: Martin Beagles. 


\section{Introduction}

In this paper, I will study how Early Modern Spanish historiography dealt with the problem of converting the Muslim calendar to the Christian one. ${ }^{1}$ This problem arose with a certain frequency in the sixteenth and seventeenth centuries, an especially significant period in historiographical terms that was defined by the writing of the great national or proto-national chronicles of Spain (Florián de Ocampo, Ambrosio de Morales, Esteban de Garibay, Juan de Mariana), and the emergence of pre-Enlightenment critical historiography. It was, in other words, a crucial moment in the creation of a historical narrative about Spain. In this context, the problem of Muslim chronology reveals itself to have been characterized by technical, historiographical and religious complexities that make it particularly significant.

In the sixteenth century, the Andalusi past of the Iberian peninsula was still quite close in time, especially in a city like Granada, and the Arab presence was not only felt in the language or surviving buildings but also in a very special way through the continued existence of the Morisco population, i.e., of those Muslims who were forcibly converted to Christianity in the early sixteenth century and were eventually expelled from Spain in 16og. In cultural terms, the problematic integration of the Moriscos within Spanish society replicated to a large extent a historiographical conflict like that of the integration of the Andalusi past within a coherent account of Spanish history. The treatment of Muslim religion as a historical phenomenon, reducible to the contingencies of time, constitutes a key development in the transformation of the religious polemic between Islam and Christianity. As has been suggested by Matthias Tischler for the case of the Spanish Middle Ages in his work on medieval chronicles, the conversion of the Muslim religion into part of one's own Christian

1 This article seeks to put flesh on an argument first sketched out in Mercedes García-Arenal and Fernando Rodríguez Mediano, The Orient in Spain. Converted Muslims, The Forged Lead Books of Granada, and the Rise of Orientalism, trans. Consuelo López-Morillas, (LeidenBoston, Brill, 2013), 395-405. It is the result of work carried out within the research projects "Islam y disidencia religiosa en la España Moderna: entre la reforma protestante y la católica" (FFI2010-17745), and "CORPI: Conversion, Overlapping Religiosities, Polemics, Interaction. Early Modern Iberia and Beyond', (FP7/2007-2013)/ERC Grant Agreement number 323316, funded by the European Research Council under the European Union's Seventh Framework Programme), directed by Mercedes García-Arenal. At an earlier stage of this research, I presented a version of my ideas at the Conference "Sola una ley se tenga: per una nuova storia delle minoranze nel mondo iberico / hacia una historia de las minorías en el mundo ibérico," Pisa, December 15-16, 2008. In its final phase, this work has benefitted from the comments of Mercedes García-Arenal, Cristina Jular, Maribel Fierro and Carlos Cañete. 
history was largely brought about by its historicization: turning Islam into a historical fact was equivalent to constructing it as an authentic religious tradition rather than a mere accumulation of immutable images and commonplace notions. ${ }^{2}$ The notion that Islam was turned into a historical fact is a correct one, but only if we consider it to have been a long and complex process. In considering the time which passed between the thirteenth and sixteenth centuries, we need to take the following factors into account: the uneven, interrupted and unsystematic history of the translation and circulation of Arabic texts in the Christian kingdoms; changes in the forms and intensity of religious polemic; and the process which in Spain led from the medieval co-existence of three religions to the confessional society of the sixteenth century via the mass conversions of Jews and Muslims. While a historian such as Cardinal Rodrigo Ximénez de Rada gave a narrative shape to the crusading frontier spirit of the thirteenth century, ${ }^{3}$ sixteenth-century historians found themselves in the midst of a process of imperial political formation which needed to found the national historical record of a society dealing with, amongst other things, the problem of the mass existence of conversos of Jewish and Muslim origin. To all of this can be added the series of technical and epistemological transformations which caused a historiographical mutation which, in the seventeenth century, was to give rise to an authentic "discovery of time." ${ }^{\text {In }}$ In the context of the construction of a new Spanish national history which was required to cope with the religious, political and epistemological peculiarities of the sixteenth century, the issue of Arabic sources and Muslim chronology started to be handled differently. ${ }^{5}$ Thus, the attempt to integrate the Muslim past in a general account of the history of Spain led to a number of questions being asked that became increasingly important: to write the history of Spain, should Arabic sources be used? What were these sources? Most importantly, perhaps, was al-Andalus part of the history of Spain?

2 Matthias M. Tischler, "Discovering Islam as a Historical Phenomenon: The Case of the Latin Historiography of the Iberian Peninsula, 8th to the 13th Century," Quaderns de la Mediterrània 16 (2011): 153-161.

3 Lucy K. Pick, Conflict and Coexistence: Archbishop Rodrigo and the Muslims and Jews of Medieval Spain (Ann Arbor, 2004), 14.

4 I take the expression from Paolo Rossi, I segni del tempo. Storia della terra e storia delle nazioni da Hooke a Vico, (Milano, 1979).

5 This article adopts a strict conception of Muslim chronology, limiting itself solely to the hegira, the subject of all the calculations made by the authors considered in it. I have therefore left aside the chronological complexity of the Muslim world, where in practice different methods for calculating time not only existed side by side but were sometimes used in a mixed manner. 
At a technical level, the chronological problem was tackled in several different phases: at first, it was seen as a problem of astronomical knowledge, i.e., of the calculation of the equivalence between the solar and lunar cycles. This equivalence had been calculated since ancient times, to a more or less accurate degree, within the field of astronomical studies. ${ }^{6}$ There were many other implications involved, however. Although the technique of calculating the different cycles was well known from an astronomical point of view, such a solution was not transmitted as such into the writing of history. This is because there was an additional issue of a non-astronomical nature. It was simple but crucial: when did the hegira begin? The answer to this question went beyond the mathematical and astronomical aspects of the problem and required all the historical, theological and dogmatic knowledge of Islam possessed by Spanish society to be brought to bear. This was a dialectical process in which the old polemical tradition of commonplace assertions about Islam and the prophet Muhammad were confronted by the demands of more accurate technical tools like chronology, and the re-assessment of non-European texts, in this case written in Arabic. However, once it had been turned into a historiographical problem, it acquired an autonomy of its own, transformed historical discourse and became entangled in the wider issue of the very possibility of writing a providential history of Spain and its origins.

For this reason, this paper will end by referring to the more global problem of biblical chronology, making use of the argument that the integration of Arabic culture in Spanish historiographical discourse was largely inseparable from a general notion of the presence of the Orient in the history of Spain, and that this was an Orient whose key reference point was the Bible. By illustrating this process, I will try to go beyond the view that the logic of the relationship between Early Modern Spain and Islam was that of the construction of an alterity or a representation of the other. This was not really the case. It was in fact a relationship which profoundly determined representations of the country's own past and the development of the critical tools with which to understand it. The limitations of this critical effort were also, to a large extent, the limitations of the validity of its models of textual and religious authority.

6 For the various religious, political, technical and ideological implications of the use of the lunar calendar and the way it overlapped with the solar calendar, see Jonathan Ben-Dov, Wayne Horowitz and J. Michael Steele (eds.), Living the Lunar Calendar (Oxford, 2012). 


\section{Chronology and Sacred History}

At the beginning of Los XL libros del compendio historial, ${ }^{7}$ Esteban de Garibay (1533-160o), one of the most significant Spanish chroniclers of the sixteenth century, laid out his reasons for deciding to open his narrative with the creation of the world and not, like other Spanish historians before him, with the story of Tubal, the descendant of Noah to whom was attributed the origin of the Spanish nation after the Universal Flood. ${ }^{8}$ The main reason given for this was "not because anything is known of the things which happened in Spain in such a great number of years as there were from the creation to the flood, but out of a desire to show the blessed holy male line from Adam, the first father of all human beings, to our patriarch Tubal, the universal father of the first true and original Spaniards." ${ }^{9}$ In order to demonstrate the originality of his project, Garibay cited the historian and Catholic bishop of Jewish converso origin Alonso de Cartagena (1384-1456), for whom all histories other than sacred ones had begun with the Flood. If Garibay chose to go as far back as Adam, it was on account of his clear intention to link the history of Spain to sacred history. ${ }^{10}$

Through this argument, Garibay took onboard a historiographical tradition which posed questions about the role and position of Spain within sacred history and in the economy of salvation. ${ }^{11}$ To cite just one example, there was the case of Alonso de Cartagena's father, the one-time rabbi and later Bishop of Burgos, Pablo de Santa María (+1435), who attempted to fit the history of Spain into a providentialist Augustinian framework in his work Las siete edades

Esteban de Garibay, Los XL libros del compendio historial de las chrónicas y universal historia de todos los reynos de España, 4 vols. (Antwerp: Christophe Plantin, 1571), I: 24 and 41.

8 Tubalism, i.e. the idea that the first settler of Spain was Tubal, a descendant of Noah, in the period after the Great Flood, and that he therefore initiated the country's "national history" was to dominate Spanish historiography until a very late period.

9 One example of the use of successive chronological inscriptions of the history of Spain, firstly with respect to the Flood, then with respect to the founding of Rome, and finally with respect to the birth of Christ, can be found in Johannes Vasaeus, Chronici rerum memorabilium Hispaniae (Salamanca, 1552).

10 For the different dates proposed during the Renaissance for the creation of the world, and chronologies of different versions of the Bible, see A. Patrides, "Renaissance estimates of the Year of the Creation," Huntington Library Quarterly 26 (1963): 315-322.

11 By sacred history I refer to historical uses of the Christian past, the history of the church and of the Bible. In the case of Spain, sacred history tries to establish a link between Spanish history and the history of salvation, underlining its providential role in this process. It therefore constitutes a historical legitimization of Spanish imperialism. 
del mundo. ${ }^{12}$ This is just one example which serves to illustrate the tradition within which Garibay placed his own attempt to locate Spain within the general framework of sacred history. ${ }^{13}$

But apart from his desire to retrace this link with sacred history, Garibay had another, more specific, aim of a chronological nature: in his history, he sought to be so accurate as to be able to give the day of the week on which the various events which he narrated had taken place. This was no simple task, as Garibay himself explained. For dates before the birth of Christ, Garibay followed the Hebrew dating system, which he described as the "true reckoning."14 The expression "cuenta hebrea" [Hebrew account, or counting system] made reference to the Bible, according to which 3961 years had transpired between the creation of the world and Christ's birth; Garibay believed, however, that this computing system had been riddled with errors during a period which started with the Greek Septuagint and continued with the contributions of the Church Fathers and the works of King Alfonse The Wise. ${ }^{15}$ Calculations after the birth of Christ were no easy matter either: to the Christian computing system Garibay had to add others, like that used during the so-called "Hispanic era" or "era of Caesar", i.e., a system used during the Hispanic Middle Ages from the fourth century onwards, and which started at the year $38 \mathrm{BC}$; and of course, there was also the Muslim hegira, used throughout the eight-hundredyear existence of al-Andalus. By means of this review, Garibay illustrated the complexity which, from his point of view, required him to construct a rigor-

12 Juan Carlos Conde, La creación de un discurso historiográfico en el cuatrocientos castellano: "Las siete edades del mundo" de Pablo de Santa María (Salamanca, 1999).

13 Garibay's importance in the history of the establishment of Tubalism in Spanish historiography is well known, as is his dependence on Annio de Viterbo. This was an undertaking which also reinforced the idea of Hebrew as the original language of the Iberian Peninsula. F.J. Perea, "Esteban de Garibay y la hipótesis hebraico-nabucodonorosiana," Estudios de Lingüística del Español 36 (2015): 177-195.

14 Garibay, Los XL libros del compendio historial, I: 41.

15 The mismatch between the different chronologies (e.g. between the calculations made in the Vulgate and the Septuagint) constitute a recurring theme in these works, which seek to trace out a "universal history" chiefly based on biblical sources. See for instance Juan de Rihuerga, Crónica de las antigüedades de España, BNE, ms. 1496, 19v-20v; Alonso Maldonado, Chronica universal de todas las naciones y tiempos (Madrid, 1624), 3v. In order to calculate the date of the coming of the Anti-Christ, Tomás de Maluenda carried out a highly detailed chronological critique of the contradictions between the version given in the Septuagint and that of the Vulgate and the "hebraica veritatis," with partial use made of rabbinic chronologies: Tomás de Maluenda, De Antichristo (Lyon, 1647), "Liber II: De tempore adventus Antichristi," $64 f f$. 
ous chronology of the history of Spain which could not be found either in the medieval histories of the country or in the writings of the Holy Fathers.

Garibay's project was thus situated at the meeting-point of two interests that were simultaneous but not necessarily convergent: first, there existed a desire to integrate Spanish history in the sacred history of Christianity which went back to the origins of mankind; second, there was a concern for chronological accuracy that was common to all European historiography in the sixteenth and seventeenth centuries. The tension between these two interests was certainly not limited to the work of Garibay. These were issues which were constructed throughout the sixteenth century via the creation of a highly important historiographical tradition of histories of Spain.

\section{Islam and the History of Spain}

One of the first "histories of Spain" to be written in the sixteenth century was that of the Valencian Pere Antoni Beuter $(+1554)$, whose work was first published in Catalan and later in Castilian Spanish. At one point in his work, Beuter points out the different dating systems "among the common people," which often established chronological reference points on the basis of extraordinary events which had occurred to the various different communities, such as the conquest of Toledo by Alfonso VI, the forced conversion of the Mudejars of Castile, the expulsion of the Jews, the sacking of the Jewish quarter of Valencia or the fire in the market of that city. Among these different "vulgar" dating systems, according to Beuter, was that of the Moors:

From this practice of counting time from certain important events there remains in Spain the diverse number of counting systems among the vulgar: some count from the year in which Spain was lost and occupied by the Moors, the year 714, when the battle of King D. Rodrigo took place, or from the year 719, in which, according to the Archbishop of Toledo, it was peacefully taken. The Moors count from the year in which Mahoma started preaching his sect, which was, according to the Archbishop, the year of Our Lord 621; but the Florentine disagrees, and says it was the year of Our Lord 640, more or less. But according to the way the Moors count the moons, they say that the moon of Saint John of June 1537 corresponds to their year 944 , so their count began the year of Our Lord $593 .{ }^{16}$

16 Pere Antoni Beuter, Crònica, ed. Enric Iborra (Valencia, 1982), 52-3. 
Expressions of doubt concerning the exact date of the Muslim conquest of the Iberian Peninsula can be found throughout the historiography of the period, with estimates mainly oscillating between the years 711 and 714. Indeed, such doubts were to become one of the recurring themes in discussions of Andalusi chronology. To some extent, they can be seen as signaling the beginning of attempts to integrate problematic events of this kind within the history of Spain. The source cited above by Beuter is the "Archbishop of Toledo", don Rodrigo Ximénez de Rada (+1247), whose work occupied a key position in the historiographical canon on the history of al-Andalus and the Reconquista. In the early decades of the sixteenth century, the use of a limited number of Latin and Castilian works such as that by Ximénez de Rada could be combined with the direct experience of contact with Muslims, especially in an area like Valencia, where forced baptisms had not taken place until 1525, more than two decades later than in Castile. Thus it was that Beuter was able to refer both to the vulgar dating system and the works of the Archbishop of Toledo. ${ }^{17}$ In addition, there were significant doubts over the date of the beginning of the hegira: Beuter cites Ximénez de Rada himself, and also "the Florentine", i.e. Saint Antonino of Florence, who had proposed the years 621 and 640. For his own part, Beuter adopts a grossly inaccurate system for the conversion of dates: although he knew that the Muslim calendar was lunar, and also that Saint John's Day 1537 corresponded to the Muslim year of 944, he limited himself to calculating the year of the start of the hegira by carrying out a simple subtraction, as if the measures of time were equal. ${ }^{18}$

The quotation from Beuter serves to illustrate the disconnect that existed during the first half of the sixteenth century between the different components of the question of Muslim chronology, i.e., the technical astronomical problem, the historiographical problem and, finally, real knowledge and use of Arabic and Muslim texts. From the astronomical point of view, for instance, the authority of several Arab astronomers and astrologers had been recognized during the European Middle Ages, creating a tradition made up of names like

\footnotetext{
17 Beuter's argument reflects the tension between one conception of time tied to specific events or themes and another that was linear and universal. See D. Wilcox, The Measure of Times Past (Chicago, 1987), 9.

18 Beuter also worked on issues of ancient and biblical chronology in his biblical commentaries, Annotationes decem in Sacram Scripturam, Valencia, per Ioannem Mey Flandrum, f. $5^{2}$ and ff. François Secret, "Les 'Annotationes decem in Sacram Scripturam' de Petrus Antonius Beuter," Sefarad 29 (1969): 319-332.
} 
al-Batțānī or al-Fargānī which extended throughout the period. ${ }^{19}$ One important moment in the construction of this tradition came with the writing of astronomical works at the court of Alfonso The Wise. The Castilian king had already formulated in his astronomical works the problem of the differences between the different eras or periods (the Alfonsine era, that of Caesar or those of the Persians or the Arabs) and that of the equivalence between them. He laid out methods for calculating such equivalences through the use of both mathematical calculation and special tables which were later to disappear. ${ }^{20}$ Such a solution cannot, however, be described as a proper historiographical method, in the sense that these operations only provide a way of calculating astronomically the equivalences between different systems but not a procedure for working out the exact date of an historical event. Thus we find that in a work produced in the circle of Alfonso The Wise, the so-called Estoria de España or Primera Crónica General, the text says when dealing with the Muslim conquest of the Iberian peninsula that this conquest "was in the month called Ramadan in Arabic; but as the Moors count their months in accordance with the moon we cannot therefore say for certain which month it was in our own language."21 Awareness of the fact that different eras had existed did not mean that it was thought necessary to calculate conversions from one to the other and integrate them in a coherent chronological apparatus. There were several reasons for this lack of connection between the historiographical and astronomical fields: on the one hand, during the European Middle Ages there was no single, unique conception of time as a linear succession of measurable units. Such a concept belonged to astronomy but not necessarily to history, where different perceptions of time existed..$^{22}$ It can be adduced, however, that throughout the periods of Late Antiquity and the Middle Ages, efforts to order history chronologically were certainly made (for example, in the genre of annals), suggesting that in the case of the hegira there must have been an additional reason for such neglect which was somehow linked to the difficult process of the historicization of Islam in Spanish historiography. Spanish astronomy could draw on

19 The literature on Arab astronomy and its diffusion throughout medieval Europe is immense. A classic in the field is Juan Vernet, Lo que Europa debe al Islam de España (Barcelona, 1999), esp. 277-292.

20 José Chabás and Bernard R. Goldstein, Las Tablas alfonsíes de Toledo (Toledo, 2008), 40-53.

21 Primera Crónica General o sea Estoria de España que mandó componer Alfonso el Sabio y se continuaba bajo Sancho IV en 1289, ed. Ramón Menéndez Pidal (Madrid, 1906), 308.

22 Gerhard Dohrn-van Rossum, L'histoire de l'heure. L'horlogerie et l'organisation moderne du temps (Paris, 1997), 296 [trans. of Die Geschichte der Stunde. Uhren und moderne Zeitordnung (Munich, 1992)]. 
a robust tradition which was to pave the way for the realization of important chronological work: for example, the influence of Salamancan astronomers on the Gregorian reform is well known; ${ }^{23}$ but this knowledge did not imply consideration of the need to integrate the different chronological systems within one historical narrative.

This disjunction between technical knowledge and historiographical narration lasted into the early modern period. As we have seen in the Beuter example, although the tools existed to calculate chronological correspondences with some accuracy, such operations were not carried out. It can be said that towards the mid-sixteenth century, even those Spanish historians who were aware of the existence of different chronological systems experienced considerable difficulty when it came to setting out the problem in reasonably accurate terms, and that they solved it by means of simple addition. ${ }^{24}$ There are various explanations for this: one is that knowledge of Islam was still influenced by a polemical tradition that was full of clichés concerning the figure of the Prophet Muhammad and was far from rigorous in its treatment of theology; in addition, there was little awareness of the need to use Arabic sources to reconstruct the history of Spain. All of this began to change decisively in the second half of the sixteenth century.

The case of the already mentioned historian Esteban de Garibay, writing in the 1560 s, is especially relevant for several reasons. First of all, one of Garibay's historiographical innovations was that he attempted to write a history of Spain based on the specific histories of the different peninsular kingdoms; thus he significantly devoted a section to the history of "Moorish kings of Spain", especially those of Cordoba, ${ }^{25}$ and another to "the Moorish kings of Granada." ${ }^{26}$ Compared with that of previous historians, this was a clearly original approach. ${ }^{27}$ His interest in Islam led Garibay to include at the end of his work an account of the life of Muhammad. In it, Garibay places the start of the hegira in the year 617 , at the moment, in his view, of the conquest of Medina by the Prophet. ${ }^{28}$ From there, Garibay calculates hegira dates by the simple

23 Ana María Carabias Torres, Salamanca y la medida del tiempo (Salamanca, 2012).

24 For example, Alonso Venero, Enchiridión de los tiempos (s.l., 1511), 6v; a narration of the origins of Islam mainly based on Platina, in $138 \mathrm{v}$ and ff.

25 Garibay, Los XL libros del compendio historial, III: 942.

26 Ibid., III: 1042.

27 Richard L. Kagan, Los cronistas y la corona (Madrid, 2010), 170. See also Martín R. Ríos Saloma, La Reconquista. Una construcción historiográfica (siglos XVI-XIX), (Madrid, 2011), 59-68.

28 Garibay, Los quarenta libros del compendio historial, III, $95^{\circ}$. 
method of subtracting 617 years from the Christian calendar. Apart from the above-mentioned inability to calculate the equivalence between lunar and solar cycles, Garibay's method reflects the traditional difficulty of pinpointing the exact moment when the hegira began. This difficulty was linked to the question of sources. Garibay himself explains which sources he is using for his history of al-Andalus: these were basically the works of Archbishop Ximénez de Rada, the so-called Crónica del moro Rasis, the works of Alfonso The Wise, the chronicle of Juan Vaseo and the Confusión o confutación de la secta mahomética by Juan Andrés. This was, in other words, the traditional corpus of medieval Hispanic historiographical work on the Arabs, plus the key anti-Muslim polemical work by Juan Andrés, published in 1515, which had a significant influence on knowledge of Islam throughout Europe. ${ }^{29}$ Such work reflected a medieval historiographical tradition, strongly influenced by the literature of anti-Muslim polemics, which fueled a great deal of European knowledge of the origins of Islam and the Prophet Muhammad. It is a tradition which, as we have seen, co-existed in Garibay with an interest in the historical dimension of Islam and chronology. Only gradually, in a slow and imperfect manner, did the chronological problem become a pressing issue in authors who, like Luis del Mármol, began to write of the need to use Arabic sources in their own works, or in others relating to the world of astrology and astronomy.

Mármol $(+1600)$ was a Granadan soldier who fought in the expeditions under Charles v to North Africa, was held captive for a number of years in Morocco, took part in the War of the Alpujarras and was eventually the author of a Descripción general de África, a work in three volumes (1573-1599). Mármol expressed his desire to write an unusual work within Spanish historiography: a vast account in which the history of Islam was mixed with a narration of Portuguese expansion in Africa to paint a portrait of the new image of the world. The main sources for his work were the Navigazioni e viaggi of Giovanni Battista Ramusio, and, above all, the Descrizione by Leo Africanus. Mármol was well aware of the historiographical novelty of his work with regard to sources: this resulted, firstly, from his own experiences as a captive in Morocco then from his reflections on "certain selected Latin, Greek, Arabic and vulgar histories of these kingdoms and beyond."30 Mármol's claim to have read and used Arabic sources is presented by him as proof of the ground-breaking nature of

29 The bibliography on Juan Andrés is extensive. See, for example, the article by Ryan Szpiech, "Preaching Paul to the Moriscos: The Confusión o confutación de la secta mahomética y del Alcorán (1515) of 'Juan Andrés', La Corónica, 41, no. 1 (Fall 2012): 317-343.

30 Luis del Mármol, Descripción general de África, vol. I (Granada, 1573), "Prólogo al lector." 
his work. However, it is not clear which Arabic sources he actually knew and used: it seems highly likely that his knowledge of Arabic was insufficient.

In his work, Mármol proposes a system for the conversion of dates which starts from the assumption that the hegira had begun in the year 613 . The lunar year is made up of six 29-day months and another six with 30 days and was therefore eleven days shorter than the solar year; thus, for every 30 -year cycle it was necessary to discount one year minus 45 days. The year in which he was writing, 1571 , therefore corresponded to the year 988 of the hegira. ${ }^{31}$ In a later work, in which he narrated the War of the Alpujarras, Mármol returned to this theme in a more detailed manner: he claimed that in Africa the solar calendar was used in agriculture, through reliance on a Treatise on Agriculture which he asserted was none other than the celebrated Calendario de Córdoba. However, wrote Mármol, Muslim jurists and theologians used the lunar calendar, which was forty-five days and six minutes shorter than the Latin year. Calculations of the hegira should begin in the year 621 , not 613 , as he had erroneously stated in his previous work. ${ }^{32}$

The truth was that Mármol's system for the conversion of dates, including the subsequent reference to the Treatise on Agriculture, were lifted straight from Leo Africanus, ${ }^{33}$ whose chronological practices were particularly imprecise. Mármol's work is one of the channels through which Leo Africanus's influence was spread throughout Spain and Europe and was thus one of the means by which a new image of Africa was constructed. ${ }^{34}$ Despite its lack of precision, and its deceitful use of sources, Mármol's work is highly important; it is a key link in a historiographical tradition which sought to locate the spatial and temporal coordinates of Islam with greater accuracy, and which brought Islam into the history of Spain. The fact is that Mármol's work remained a constantly cited source, often only in order to criticize him, and one which explicitly formulated the relationship between the history of Islam in Spain, the use of Arab sources and the desire to find a method for converting hegira dates. Mármol's work was published at roughly the same time as that of Esteban de Garibay and the work of both authors illustrates how, in the 1570s, the problem of the

31 Luis del Mármol, Descripción, I, 55r-55v.

32 Luis del Mármol, Historia del rebelión y castigo de los moriscos del Reino de Granada (Granada, 2004), 44-45.

33 Leo Africanus, Descrizione dell'Africa, in Giovanni Battista Ramusio, Navigazioni e viaggi, ed. Marica Milanesi (Torino, 1978), I: 58-9.

34 Fernando Rodríguez Mediano, "Luis de Mármol lecteur de Léon. Une appréhension espagnole de l'Afrique," in Léon l'Africain, ed. François Pouillon, with Alain Messaoudi, Dietrich Rauchenberger and Oumelbanine Zhiri (Paris, 2009), 239-267. 
presence of Islam in the history of Spain had come to encompass some key historiographical elements such as the use of Arabic sources, chronology, or the existence of medieval Muslim kingdoms that were on a par with Christian kingdoms. This interest in Islam can be connected to a wider problem running through Spanish (and perhaps European) historiography of the second half of the sixteenth century, that of a localist reaction against Roman humanism, which led historians to search for other sources of historical legitimacy, such as the Goths or, above all, the Orient as represented in the Bible. ${ }^{35}$

\section{The Influence of Luis del Mármol}

Mármol's system was taken up by Ambrosio de Morales (+1591), one of the most important Spanish sixteenth-century historians. In one of his major works, the continuation of the chronicle of Spain by Florián de Ocampo (one of the first "national" chronicles), Morales included an introductory chapter which dealt with "The years of the Arabs and the difference between them and those of the birth of Our Redeemer." In it he explained that, given that he intended to discuss the wars of Spain against the Arabs, it was necessary to know their means of counting years, "so that a great many things will be understood which without taking notice of this could not be known." To make the conversion, Morales placed the hegira in the year 618, like Archbishop Rodrigo Jiménez de Rada before him. ${ }^{36}$ Starting from that date, Morales explicitly followed Mármol's method. However, Morales added, this calculation was difficult to make, for the chronological concordance was not perfect. Thus it was that, knowing for certainty the years of the Christian and Hispanic eras, "this good account was not harmed or altered in any way by the fact that a Moorish king had started or ceased to reign four or five years earlier or later." This was, then, a difficult and troublesome method, and Morales thought it was not worth "tiring oneself out... over an issue of such little importance and so much hard work." Such a statement is even more significant if we remember that for Morales, as for other historians of his generation, chronology was seen as the

35 Pablo Fernández Albadalejo, “'Materia de España’ y 'edificio’ de historiografía. Algunas consideraciones sobre la década de 1540," in La encuadernación: historia y arte (Madrid, 2001), 135-163.

36 Rodrigo Jiménez de Rada, Historia arabum, ed. José Lozano Sánchez (Seville, 1974), 13. Jiménez de Rada gave this date as that of Muhammad's proclamation as king in Damascus. Morales speaks more vaguely of the moment when "Muhammad rose up and started his conquests with a great army." 
key to historiographical activity, and one which demanded extreme rigor and precision. ${ }^{37}$ This is the expression of a stance which was to become frequent among Spanish historians: even though a difference between the two dating systems was known to exist, calculations of their equivalence were madewhen they were made at all-in an incorrect manner, by means of a simple addition or subtraction; or rather, the effort was deemed pointless because nothing could be learnt from Arab sources which could not contribute to any possible account of the history of Spain.

While the method used by Mármol and Morales can be traced back to the work of Leo Africanus, another tradition more closely linked to astronomical studies lasted into the sixteenth century. As has been explained, many works on chronology put forward the problem of lunar years and the Muslim calendar but in an entirely technical, abstract manner, as an issue completely detached from the question of date conversion and, thus, from its historical dimension..$^{38}$ One case that was different, however, was that of Diego Pérez de Mesa, an unusual figure who stood out as a result of the diversity of his interests. He was an astronomer and mathematics professor at the universities of Salamanca, Alcalá de Henares and Seville, and also carried out a certain amount of work as an Arabist, at least during his stay in Rome as adviser to the Spanish ambassador Gaspar de Borja (1631-1634). Testimony of this role exists in the form of a copy written out in his hand of al-Risāla al-hārūniyya, and dedicated to Cardinal Francesco Barberini, nephew of Pope Urban ViII. ${ }^{39}$ In Rome, he coincided with the political thinker Diego Saavedra Fajardo $(+1648)$, who considered astrology a way of linking the human universe with the divine will, and of conferring moral order on the imperfect and changeable political world of men..$^{40}$ In the case of Pérez de Mesa, an interest in both astronomy and Arabic studies came together in his historiographical work. He published his edition of Pedro de Medina's Grandezas y cosas notables de España in 1590. In it, Pérez de Mesa provided a thoroughly corrected and augmented re-edition of a work by Pedro de Medina $(+1567)$. With a strong sense of the value of experience and direct observation, Pérez de Mesa intro-

37 Ambrosio de Morales, "De la mucha diversidad que ay en las maneras de contar los años, y las difficultades que desto proceden [...]," in Los otros dos libros undécimo y duodécimo de la Corónica General de España (Alcalá de Henares, 1577), 6v.

38 For example, Francisco Vicente de Tornamira, Chronographia y repertorio de los tiempos a lo moderno [...] (Pamplona, 1585), 395.

39 Biblioteca Apostolica Vaticana, Barb. Or., 83.

40 Abel A. Alves, "Complicated Cosmos: Astrology and Anti-Maquivellianism in Saavedra's Empresas Políticas," Sixteenth Century Journal 35, no. 1 (1994): 67-84. 
duced items of geographical information which he had gathered himself, such as the latest cosmographical data and digressions on the natural sciences or chronology. ${ }^{41}$ One of these digressions included a method for converting dates of the hegira ${ }^{42}$ For Pérez de Mesa, lunar or Arabic years had been used by the Romans, Greeks and Hebrews, and the difficulty of calculating their equivalence was a source of much obscurity, especially because "there are many Arab histories of Spanish events" which needed to be understood. ${ }^{43}$ Through his knowledge of astronomy, Pérez de Mesa was in a position to be much more precise when it came to laying out the technical terms of the problem: each lunar cycle comprised 29 days, 12 hours and 44 minutes, and in order to fit such a measure into an annual period of twelve months, he established a division of six 29-day months and six 30-day months, giving him a year that was 354 days, 8 hours and 48 minutes long. This obliged him to introduce an extra day in the last month of certain years, in the same way that the solar cycle made it necessary to introduce one day every four years. These additions were to be made in cycles of thirty years, of which the second, fifth, tenth, thirteenth, sixteenth, eighteenth, twenty-first, twenty-fourth, twenty-sixth and twenty-ninth were to receive an extra day. This calculation is essentially correct, including the part referring to the years which needed to be given extra days (except the missing seventh year, which may have been left out by mistake), and although it is not the only system in existence, it is in fact the most widely used system in the Muslim world. Such information, it has to be said, appears quite frequently in Arabic books on astronomy (such as those by al-Batțānī), and was already well known in the Hispanic Middle Ages, as is shown for example, with some differences, in the Tablas of Alfonso The Wise, cited above. ${ }^{44}$ Indeed, the two sources cited by Pérez de Mesa are the works of Alfonso and the Computus maior by Campano de Novara.

When was the start of the hegira? According to Pérez de Mesa, it was "Thursday six hundred and twenty-one years and one hundred and ninetyfive days into the era of our Redeemer Jesus Christ"; 45 that is to say, on July 15, 622. Again, Diego Pérez de Mesa's information on this point is essentially correct: the Muslim era did not begin at the moment of Muhammad's journey

\footnotetext{
41 Luciano Pereña, "Estudio preliminar: I.- Política o educación democrática," in D. Pérez de Mesa, Política o razón de estado (Madrid, 1980), xix-xxiv.

42 Pedro de Medina and Diego Pérez de Mesa, Primeray segunda parte de la grandezay cosas notables de España (Alcalá de Henares, 1595), 1st part, Chpt. XVII, 18r-2or.

43 Ibid., f. 18r.

44 Chabás and Goldstein, Las Tablas alfonsíes, 40.

45 Medina and Pérez de Mesa, Primera y segunda parte de la grandeza, $18 \mathrm{v}$.
} 
to Medina, which must have taken place on September 15 or 16, 622, but on the first day of that lunar year, the first of muharram, which coincides with July 15 or with Friday July 16, in the year 622 . Starting from that day, Pérez de Mesa proposes a complex arithmetical method for calculating the equivalence between the two dating systems. He added also a table with the name and duration of each of the Muslim months. Up to this point, he had followed the method of Campano de Novara; ${ }^{46}$ a method that he also used, in an inverted manner, to convert Muslim years into Christian years. The most interesting aspect of this idea was not perhaps its originality so much as a commentary made by Diego Pérez de Mesa: "[If] I find in Arabic history that a certain event took place in the year nine hundred and ninety-six on the thirtieth day of the fifth month, which they call the first of Jumedi [...]."47 This quotation clearly reveals the historiographical urge behind Pérez de Mesa's efforts, and which can be assumed to have been an inseparable part of his status as a scholar who was familiar with the Arabic language: the need to transform the dates found in Arabic works of history. At all events, Pérez de Mesa harshly criticized the methods proposed by Ambrosio de Morales and Mármol because of their lack of technical skills. 48

In contrast, Diego Pérez de Mesa's position is that of a "professional astronomer" familiar with the techniques that were necessary for the carrying-out of his task, i.e., that of chronological accuracy. His case is significant because his double status as mathematician and historian meant that both interests were able to come together in one sole tradition. However, Pérez de Mesa did not write a history of Spain or al-Andalus; instead he edited a book belonging to a genre, that of the grandeurs of Spain, which relegated him to a relatively marginal place outside the canonical current of Spanish history-writing in which, for instance, Ambrosio de Morales was a well-known and widely read author throughout the sixteenth and seventeenth centuries.

46 Campanus a Novara, Computus maior, in Johannes de Sacro Bosco, Sphera cum commentis... (Venice, 1518), 168r. One of the uses of Campano's work was precisely that of calculating the chronological equivalence of the hegira. See for example the fourteenthcentury manuscript from the Bibloteca Nazionale Centrale of Florence which contains an "Inventio annorum et mensium Arabum per annos et menses Christi secundum magistrum Campanum," in Lynn Thorndike, "Notes upon some Medieval astronomical, astrological and mathematical manuscripts at Florence, Milan, Bologna and Venice," Isis 50 (1959): 33-50, 38 .

47 Medina and Pérez de Mesa, Primera y segunda parte de la grandeza, $19 \mathrm{v}$.

48 Ibid., f. 2 or. 


\section{Juan de Mariana}

The Jesuit Juan de Mariana was also an immensely well-known and widely quoted historian. Mariana's Historia General de España was first published in Latin in 1592, and was translated into Spanish in 1601. Although Mariana was not a royal historiographer like Morales, ${ }^{49}$ his work constitutes, in spite of its errors and polemical features, a model of historical rhetoric, which almost immediately became a recognized historiographical landmark. His treatise De Rege et de regis institutione (1599) was publicly burned in Paris at the request of the Sorbonne - the book was accused of having inspired the assassination of Henri IV on account of its justification of regicide. ${ }^{50}$ Moreover, his volume Tractatus VII (Cologne: Anton Hierat, 16og) had immense repercussions, especially on account of its treatises "De monetae mutatione" and "De morte et inmortalitate," which carried harsh criticisms of the economic policy of the Hispanic monarchy, and of the corruption of the civil and ecclesiastical authorities. Such criticism was to earn Mariana a trial at the hands of the Inquisition. ${ }^{51}$ Mariana's idea of corruption depended to a large extent on his concept of time and history as political agents capable of eroding institutions. ${ }^{52}$ As in the work of Saavedra Fajardo, time featured as an untiring actor in history and political drama.

Mariana deals on two occasions with the subject of the Arab chronological system. In the Historia General de España, Mariana includes a short section on the theme as a prelude to his account of the Muslim conquest of the Iberian Peninsula. In that section, Mariana writes a brief review of the difficulties involved in squaring the solar and lunar cycles, and he also covers the evolution of the solar calendar from the times of the ancient Romans. His description includes mention of the successive adjustments, like the epacta or "golden number," which not only sought to correct the difference between the cycles but also to make adjustments for the moveable feasts such as Easter. The culmination of these efforts in the Christian world had of course been the Gregorian reform. This was, at all events, an adjustment which had not been carried out by the Moors (i.e., "Muslims"), who had borrowed their

\footnotetext{
49 For Mariana's relations with the monarchy, see Richard Kagan, Los cronistas, 171.

5o Harald E. Braun, Juan de Mariana and Early Modern Spanish Political Thought (Hampshire, 2007).

51 Gonzalo Fernández de la Mora, "El proceso contra el Padre Mariana," Revista de Estudios Políticos 79 (1993): 47-99.

52 Henri Méchoulan, "Le travail du temps dans l'œuvre politique de Mariana," Archives de Philosophie 49 (1986): 545-559.
} 
computing system from the Arabs, "because they have obstinately maintained their ancient custom until today." 53 It was from this that the grave problem of calculating the equivalence between the two systems derived, and as always this problem had to be formulated from two points of view: that of the relationship between the solar and lunar cycles, and that of determining the exact moment when the hegira began.

Mariana's chapter pointed to a set of chronological issues which seem to have occupied most of his interest, and such issues were the subject of two more extensive works, "De die mortis Christi" and "De annis arabum cum nostris annis comparatis," treatises forming part of his Tractatus VII. These two treatises are in fact complementary and follow the discourse which, as we have seen, Mariana had laid down in the Historia: establishing the date of the death of Christ formed the basis of a global conception of the calendar, in which it was necessary to adjust the calculation of time through the use of astronomical cycles, but also the sacred calendar and the adjustment mechanisms of the moveable feasts; the entire apparatus of the Gregorian reform was seen as the culmination of a method for ordering sacred time. Reading the two treatises together, as they are published in the book, produces the sense of an attempt to integrate the Muslim calendar into the structure of human history, and in particular that of the history of Spain. To a large extent, Mariana's work led, in Spain, to the conceptual union of a technical astronomical apparatus with a historiographical narrative, something which had not been possible in the work of earlier historians.

In "De annis arabum," Mariana provides a perfectly adequate account of the technical terms of the issue, in which he discusses the different lengths of the solar and lunar cycles, and the characteristics of the Arabic calendar. He cites the example of the Muslim astrologers' decision not to insert a thirteenth month every three or four years to adjust the system to the solar cycle, ${ }^{54}$ and its ordering in cycles of 30 years, of which eleven are intercalary and thus add an extra day to the last month of the year: these were the second, fifth, seventh, tenth, thirteenth, sixteenth, eighteenth, twenty-first, twenty-fourth, twentysixth and twenty-ninth years. In other words, Mariana highlights the same

53 Juan de Mariana, Historia general de España. Compuesta primero en latín, después buelta en castellano por Juan de Mariana, D. Theólogo, de la Compañía de Jesús, 2 vols. (Toledo, 1601) I: Book 6, Chpt. XXVI, 409: "De los años de los árabes."

54 One tradition interprets a difficult ayah in the Quran as meaning that the Prophet Muhammad forbade the inclusion of the thirteenth month, making the Muslim calendar a purely lunar one. However, the intended meaning of this ayah is far from clear and has been disputed by experts. See Encyclopaedia of Islam, 2nd edition, sub voce "Ta'rīkh". 
cycle pointed out by Alfonso The Wise and al-Batțānī. The main problem for Mariana was that of the extraordinary diversity of opinion among authors concerning the issue of when the hegira began:João de Barros, Girolamo Ramusio, Campano de Novara, Luis del Mármol, Esteban de Garibay, Isidoro Pacense, Rodrigo Ximénez de Rada, Juan Vaseo, the Cronicón of Juan Biclarense, the Compostelan, Complutense and Toledan Annales, Ioannes Lucidus, Alonso de Palencia, Gerardus Mercator, Onofrio Panvinio, Gerard Génébrard, Diego de Covarrubias, Matteo Palmieri, and Marco Antonio Sabellico had given years such as $593,594,613,614,617,618,620,622$ and $623 .{ }^{55}$ Although, as has been remarked, the technical problems of date conversion had been resolved since antiquity, Mariana came up against a wider historiographical panorama made up of a mixture of the old and authorized medieval Hispanic sources, early modern historians of Spain, experts in Arab issues like Mármol or experts in the history of Portuguese imperial expansion like Barros, chronologers, geographers and others. This was a wide bibliography, in which Mariana found proof of an extraordinary diversity when it came to seeking to establish the origin of the Muslim hegira.

In order to resolve the problem, Mariana began from the ides of January 1584 , a date which he says coincides with the passage from the year 991 to that of 992 in the hegira. Starting from that date he works backward, according to the lunar cycle, to reach the conclusion that the hegira began at the ides of July 622. In order to confirm the validity of this result, Mariana cites several forms of testimony, "ancient and recent," among which he includes not only historical chronicles or works on chronology but also ancient documents, epigraphical inscriptions, direct testimony, etc. Initially, Mariana cites the Toledan Annals, al-Bațtānī, the Alfonsine Tables and the authority of Scaliger, texts which pointed to the year 622 as the start of the hegira. Mariana simply highlighted his disagreement with some of them, such as Scaliger, concerning the exact day on which it began: Scaliger had given July 16 as the correct date, but Mariana preferred the fifteenth. Later, Mariana points out those references which coincide with his own correspondences or criticizes erroneous references: thus it is that he reviews the work of Isidoro Pacense and the Mozarab Álvaro, the General Estoria of Alfonso The Wise, the Chronicon Albeldense, Averroes, and Leo Africanus (whose numerous chronological errors he points out, though not without remarking that the author was a generally attentive and diligent man who had renounced his original Muslim faith). But he also uses another type of references, pointing to an inscription on the bridge of Alcántara; an inscription in the Alhambra; letters sent between King John I 
of Castile and the Sultan of Egypt, or between Suleyman the Magnificent and the Emperor Ferdinand; the opinions of Cansino, a Jew from Tlemcen; or the oral information provided by a "dux maurus" living in Talavera. Mariana's treatise ends with tables showing the correspondences between the era of Caesar or the Hispanic era, the Christian era and the "Years of the Arabs" up to the year 1749 .

The names cited by Mariana are explicit with regard to his historiographical programme. This is no longer a case of using a certain medieval astronomical or polemical tradition but of its integration in a historical account which uses tools such as archaeology, chronology or geography. The citation of Scaliger is significant: the reception of the French scholar in Spain was problematical, with both his status as a Calvinist and his alleged attacks on certain aspects of the history of Spain provoking strong reactions. ${ }^{56}$

Although Juan de Mariana was by no means the first author to resolve the problem of the conversion of dates in the hegira, his work does represent an important reference point, given that his authority as an historian was immense. To a great extent, it can be said that after Mariana, the issue of Muslim chronology acquires its full significance within a historiography which had assimilated the demands of historical chronology, which were decisive in the definition of coetaneous practices. ${ }^{57}$

\section{Arabic Sources for the History of Spain:The Marquis of Mondéjar}

Mariana's influence on seventeenth-century historiographers was enormous, in both Spain and the rest of Europe. However, in spite of his intellectual authority, his work was always the subject of constant discussion and polemic. Apart from those works already cited, i.e., those which concerned his political and economic ideas, the Historia de España was also the focus of several scholarly and religious disputes, some of them highly charged, as in Pedro Mantuano's Advertencias a la historia del Padre Juan de Mariana (Madrid: Imprenta Real, 1613), a bitter attack on some aspects of the Jesuit's work, such as his skeptical

$5^{6}$ See, for example, the works of the Jesuit Martín del Río (Vindiciae aeropagiticae [... ] contra Iosephum Scaligerum) or those of Francisco de Quevedo (España defendida). Pablo Jauralde Pou, Francisco de Quevedo (1580-1645) (Madrid, 1998), 208-210, 253.

57 Anthony T. Grafton, "Joseph Scaliger and Historical Chronology. The Rise and Fall of a Discipline" History and Theory 14, no. 2 (May 1975): 156-185. 
remarks about the journey allegedly made to Spain by Saint James. ${ }^{58}$ This was a particularly delicate issue in the Spain of the period, given the doubts which some foreign historians, such as Cardinal Baronio, had expressed concerning the veracity of the apostle's presence and preaching activity in Spain. It was on account of the affair of the apostle Saint James, among others, that Mariana earned in certain circles the reputation of being "anti-Spanish."

As far as the chronological problem is concerned, the reception of Mariana's work provides a very good reflection of the difficulties that arose when authors sought to incorporate Islam in a coherent historiographical project. Firstly, there was frequent repetition of the idea that several different sources were inconsistent in their estimations of the date of the start of the hegira. The idea was repeated, for instance, by José Pellicer (1602-1679), a highly controversial figure who became a polymath of dense and bungling erudition, a commentator on the poet Luis de Góngora and an official Chronicler of Castile (1629), Aragon (1637) and, finally, of the whole Spanish realm (1640)..$^{59}$ Pellicer explains these inconsistencies of the sources concerning the start of the hegira by claiming that there were in fact two different computational systems: that of the Arabs ("the Arabs counted the years from the day of the coronation of the false prophet Muhammad, which was on the twenty-third of May in the year of Our Lord six hundred and twenty-seven"); and that of the hegira ("until by edicts they were commanded to count from the day of the Alhijera or peregrination of Muhammad to Mecca [...], which began on Thursday the fifteenth of July of the year six hundred and twenty-two; and there is a distance between one epoch and the other of some four solar years, ten months and eight days"). ${ }^{60}$

In fact, the idea of an alleged uncertainty over when the hegira began is a topos that persisted from the sixteenth century onwards. It featured, for example, in the work of the mercenary Jerónimo Monterde, who wrote in 1686: "If historians did not vary so much in their accounts of the year of Muhammad's birth and the year in which his depraved and infernal sect began [...] all

58 Mariana was defended, in response to Mantuano, by Tomás Tamayo de Vargas, Historia general de España del P. D. Juan de Mariana, defendida por el doctor don Thomás Tamayo de Vargas contra las advertencias de Pedro Mantuano (Toledo, 1616).

59 R. Kagan, Los cronistas, 329-340.

60 José Pellicer, Annales de la Monarquía de España después de su pérdida, Madrid, Francisco Sanz, 1681, 11-2. See also, by the same Pellicer, Epithoma Imperatorum vel Arabum Ephemerides, atque Hispaniae Chronographia sub uno collecta ab Issidoro Paccensi Episcopo, in J. Pellicer, Obras varias, BNE, Mss. 2239, 245r and ff., and esp. 283r and ff., where he traces the start of the hegira to July 15,622 , following Isidoro de Badajoz, but with reference also to al-Makin and al-Idrisi. 
computations would be accurate." ${ }^{\prime 1}$ Monterde believed that although the hegira was based on the lunar cycle, the additions of days every nineteen years were enough to make it equal to the solar cycle; such an equivalence permitted him, eventually, to adjust his calculations to determine, through numerical prophesies, the dates of the end of the Ottoman Empire and of Islam. ${ }^{62}$ The allusion to the 19-year cycle, instead of the 30-year cycle that was part of the Muslim calendar, reveals the existence of a notion to which I will return below, that of a supposed continuity between the Hebrew and Muslim calendars as alleged lunar cycles.

The other problem of the reception of Mariana's work relates to the use of Arabic sources. This was an essential problem, which was re-formulated every time that the issue of the worth and consistency of the sources available on the history of Islam was raised. This issue was key to the work of Gaspar Ibáñez de Segovia, Marquis of Agrópoli and Mondéjar (+1708), a central figure in Spanish intellectual history in the second half of the seventeenth century and a man who was also central to the elaboration of a critical discourse, of Orientalist leanings, on the place of Islam in the history of Spain. Whilst recognizing Mariana's worth as a historian, Mondéjar nevertheless wrote a series of Advertencias a la historia del Padre Juan de Mariana, ${ }^{63}$ consisting of a list of aspects in the Jesuit's text which could be corrected or improved. In the "Advertencia LXXV," referring to the passage in which Mariana discusses the Umayyad and Abbasid caliphates, Mondéjar criticizes the confused nature of the information provided, which had been recognized by Mariana himself ("it shall be permitted to use conjectures in affairs as obscure as those of that nation", i.e., the Arabs), because "one cannot simply, without taking notice of the Arabs and their writings, stop making continuous absurd mistakes, as happens to Luis del Mármol at every step." ${ }^{\prime 4}$

61 Jerónimo Monterde, Espejo sacro profético a favor de la Iglesia, contra el imperio otomano y la secta mahometana (Valencia, 1686), 25.

62 Jerónimo Monterde, Juizio, según letras humanas y divinas, de la destrucción y aniquilación del imperio otomano y agarenos y recuperación de los lugares santos (Valencia, s.d.). Monterde cita al Padre Manoel de Sa, Notationes in totam Scripturam Sacram (Lion, 16og), 17-18, which comes to this conclusion in a commentary on chapter 12 of Exodus, but with reference to the Hebrew calendar, not the hegira. For a conception of the origins of Islam and the conquest of Spain based on the astrological logic of planetary conjunctions, see Gaspar Escolano, Década primera de la historia de Valencia, facs. ed. from the ed. 1610 (Valencia, 1972), vol. I: col. 336 and 337.

63 I quote from the Madrid edition: Imprenta Real, 1795. The prologue by Gregorio Mayáns is highly important in the study of the reception of Mariana's Historia.

64 Marqués de Mondéjar, Advertencias, 91-2. 
This objection was extended to include all the information given by Mariana on the Arabs, since "the information concerning the Arabs to be found in the work of European writers is extremely obscure and confused, for they have not dedicated any time at all to the scholarship written in a language which is so unusual and generally felt to be so unnecessary for the writing of their histories." However, in Spain, books on history had "to rely continually [on Arab historians] for the events which occurred in Spain on account of their unhappy dominion over it," and for this reason Mondéjar himself had decide to correct Mariana in accordance with the information "preserved in the Arab authors, who give such information differently and without errors." ${ }^{55}$

Writing in the second half of the seventeenth century, the Marquis of Mondéjar was able to make a crucial criticism of all Spanish historiography on the subject of Islam, including the work of Luis del Mármol and Fray Jaime Bleda, author of a Corónica de los moros de España and, moreover, an apologist for the expulsion of the Moriscos. Generally speaking, the historiographical canon of sources for writing the history of the Muslims of Spain had varied very little up to the seventeenth century, and the brief summary Mondéjar made of them provided the same result:

But although [the works of] some Arab writers on this sacrilegious expedition [the conquest of the Iberian Peninsula in 711] have been preserved, as has been recorded by Monsieur D'Herbeloth in his Bibliotheca Orientalis, not one of them has yet to see the light of day, although many of their main expeditions are in the Cronicón of Isidoro Pacense, if the copy published by Fray Prudencio Sandoval was not so corrupted, like that which is cited by Archbishop Pedro de Marca in the Historia de Bearne, from whose evidence Father Pedro Abarca and Don Joseph Pellicer were able to write accounts of their tyrannical conquest better than Luis del Mármol and Fray Jaime Bleda [...] and the other events of theirs which took place in Spain were collected together by Garibay, though much abbreviated, and are repeated in a rather altered form by a thousand other writers. ${ }^{66}$

65 Ibid., 94-95. The same caveat can be found in the introduction by Mayáns to the 1795 edition of the Advertencias of Mondéjar, xxiv.

66 Marqués de Mondéjar, Noticia y juicio de los más principales historiadores de España, que a persuasión de la Exc. ma Señora Doña María de Guadalupe, Alencastre y Cárdenas, Duquesa de Aveyro, \&c., escribió [...]. Con algunas cartas al fin escritas a dicho Señor Marqués (Madrid, 1784), 43-45. 
The use of Arabic sources represented, in Mondéjar's view, a crucial element in an understanding of Spanish medieval chronology because of the existence of al-Andalus. ${ }^{67}$ The problem was that, except for the works cited by Barthélemy D'Herbelot (+1695) in his Bibliotheca Orientalis, the canon of Andalusi historiography was made up of a tradition going back to the so-called Crónica mozárabe, attributed to Bishop Isidoro Pacense, and which had continued on until the work of Garibay. Indeed, an important part of Mondéjar's own historical work was guided by a double aim: a revaluation of Oriental languages and a chronological purging of Spanish history. Mondéjar devoted several works to these two topics, and some of these were included in a book, the Obras chronológicas, compiled and edited by Gregorio Mayáns y Siscar in 1744. This scholarly work was divided into two parts, one on the Hispanic era and the other on the hegira. Both were seen as fundamental and complementary elements of the problem of Spanish chronology, and their singularities with respect to other European chronologies. Such an understanding of the issue was expressed by the words written in 1732 by Pablo Yáñez de Avilés on the Hispanic era: the diplomatic discussions of Daniel Papebroch and Jean Mabillon had not taken into account extant Hispanic documents, records and diplomas, despite the fact that "no nation possesses records as easy, clear and long-lasting" as Spain:

those foreign chronologers who have information on such dated records from Spain sometimes follow it, sometimes ignore it, sometimes alter it, and sometimes contest it, with so many sophisms that finding their proofs in the Hebrews, Egyptians, Greeks, Macedonians and other indisputable accounters, assessing them by arithmetical means and raising them to astronomy, they come to seem irresistible, demonstrable and even unchallengeable, thus smothering our written records and confounding our historical transcriptions. ${ }^{68}$

The singularity of Spanish chronology had been overlooked by great European scholars in spite of its great antiquity and continuity; the emphasis on these two aspects was of course underpinned by a national vindication in defense of Spanish history and its providential outcome against foreign historians who

67 "The loss of Spain should be studied in the works by Arab authors as well as our own," Examen chronológico del año en que entraron los moros en España (Madrid, 1687), 7.

68 Pablo Yáñez de Avilés, "Prólogo sobre las escrituras antiguas en sus Postdatas," in De la era y fechas de España, chronología española, regla de las de Occidente (Madrid, 1732). 
were unaware of the merits and grandeurs of Spain, or who maliciously concealed them. ${ }^{69}$

However, although the Hispanic or Caesarian era could easily be reclaimed as Spanish historical heritage, the same did not occur with the hegira, which was indisputably Muslim. As Mondéjar had said, the question of calculating the conversion of Muslim dates continued to be problematical because the main issue of the use of Arabic sources and knowledge of Islam was still unresolved.

The Marquis of Mondéjar focused his criticism of Pellicer on this topic of the alleged inconsistency of the available sources concerning the origins of Islam. According to Mondéjar, Pellicer had made uncritical use of two different sources of information: on the one hand, that which was given by Rodrigo Ximénez de Rada and which claimed that the Muslims appointed Muhammad king after conquering Damascus; on the other, the statement by Mariana that the hegira began when Muhammad proclaimed himself king. According to Mondéjar, Pellicer had made a connection between the two pieces of data, and had dated them both in the sixth year of the hegira on the basis of information in Elmacinus, who had written that Muhammad had been proclaimed on that date. Mondéjar's criticism is certainly very interesting: it points up a typical use of contemporary scholarship, which limited itself to accumulating texts and various different authorities within one discourse without ever making a true critical assessment of the different views expressed. In addition, in Pellicer's text and in Mondéjar's criticism of it a third source appears: Elmacinus, a Christian Arabic chronicle held in great esteem throughout Europe and very widely read in scholarly circles because it constituted the first great Arabic chronicle to be printed and translated in Europe. ${ }^{70}$ This text had been edited and translated into Latin by the printing press of Thomas Erpenius. ${ }^{71}$ Here again, Mondéjar points out the uncritical use that Pellicer had made of this Arabic source: in the passage used by Pellicer on the acclamation of Muhammad in the sixth year of the hegira, Mondéjar emphasizes that Erpenius's Latin translation read

69 Yáñez de Avilés was the author of a book entitled España en la santa Biblia (Madrid, 1733).

70 See, for instance, Alastair Hamilton, Arab Culture and Ottoman Magnificence in Antwerps's Golden Age (London, 2001), 90-91.

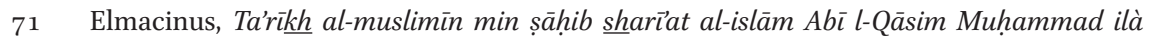
dawlat al-atābakiyya [...]id est, Historia Saracenica [...] (Leiden, 1625). The volume contains an edition of the Historia Arabum by Rodrigo Ximénez de Rada. Moreover, among the manuscript papers of Pellicer can indeed be found the "Apuntamientos sacados de la Historia Sarracenica compuesta por Gregorio Elmacino hijo de Abuljaser," F. Rodríguez Mediano, "Fragmentos de orientalismo," 267. 
inauguratus est, "without noticing that the Arabic term estajar denotes that universal acclamation with which he was received as their head and main leader by those who until that time had only been deceived into believing that he was a Prophet of God."72 In other words, Pellicer had not collated Erpenius's translation with the Arabic original. Although Pellicer claimed to know many foreign languages and had elsewhere written of his intention to learn Arabic by the king's command, ${ }^{73}$ he is fairly unlikely to have known the language well enough to be able to read texts written in classical Arabic.

A more fully realized version of this idea of the alleged variability in the calculation of the hegira can be found in the work of another Jesuit, Father Josef de Moret, author of the Annales del Reyno de Navarra, ${ }^{74}$ which contained an appendix on the subject of "Del año de la pérdida general de España" (The year of the general loss of Spain). This appendix was written in response to an "autor grave" (grave author), almost certainly the Marquis of Mondéjar himself, who had dated the Muslim conquest to the year 711, rather than 714, the generally preferred date among historians of Spain. In defense of the date of 714, Father Moret began by stating that he would not use the Muslim calendar, for "it is not an apt means to conclude and make solid and completely certain proofs of the correct time that is sought," given that there was no way to know how to date the start of the hegira, nor its correspondence with the Christian year. Such variability was proven by the huge differences on display among historians, which "could not be any greater."75

This variability was believed to be found not only among historians, but among Muslims themselves, given that "there is so much variety and contradiction among them that one cannot rely on their sayings." As an example of one who had lived among the Moors and was notably inconsistent, Moret cited Luis del Mármol, "who lived among them for so many years and learned so slowly to recognize their affairs and their Writers." Moret's final support for his argument came by adding that in sum, it required a great deal of effort to pinpoint the start of the hegira, and such a task was not worth the effort, because the history of Muhammad was unworthy of so much attention, and because the Caesarian and Christian systems were fixed and stable and a

\footnotetext{
72 Marqués de Mondéjar, Examen, 62.

73 José Pellicer, Avisos históricos, selection Enrique Tierno Galván (Madrid, 1965), 103-4.

74 Joseph de Moret, Annales del Reyno de Navarra, vol. I (Pamplona, 1684). I made reference to this discussion in my article "Al-Andalus y la lengua árabe en la España de los siglos de oro", in Al-Andalus / España. Historiografías en contraste, siglos XVII-XXI, ed. Manuela Marín (Madrid, 2009), 1-20.

75 J. de Moret, Annales, Appendix II, 31.
} 
more certain means of drawing conclusions than their [the Muslims] vague and shifting hegira, over which their own authors trip and stumble, as people who never were careful." ${ }^{\prime 76}$

The Marquis of Mondéjar's reply to these arguments was resounding: to the claim that the Muslims differed greatly amongst themselves in their dating methods he said

it is quite clear that since the Spaniards have completely banished the Moors from their country, all memory of Mahommedism there had been wiped from memory such that no trace is left. If these experts had any dealings with Muslims they would know that there is no disagreement whatsoever among them as far as calculating the hegira is concerned, from the Moluccas and the furthermost islands of the East as far as the Atlantic Sea, and where there is some difference among them it is no more than one day at the most: some begin the muharram of the first year of the hegira on the fifth feast day in accordance with the half-movement of the moon and others start from the sixth because of its phase, as is taught us by the wise prince Ulugbech in his treatise on the best-known Ephocas. And there cannot be differences among these people about the date of the hegira for it is to them a holy thing.

Given that the hegira was sacred to the Muslims, added Mondéjar, "I would like to ask how the sequence might have changed among those peoples without them finding such an alteration repugnant."77

For Mondéjar, the issue was essentially quite simple. Moret had never read a single book in Arabic, and it was for this reason that he did not know that "since the times of the caliph Omar there have been no differences in the dating of the hegira." The Muslims had determined with great accuracy the moment at which the hegira began, and only differed in this respect by one day, "the $15^{\text {th }}$ or 16th July of the year 622 of the Dionisian or Julian calendar [...] The Arabs instituted this epoch with [great] exactitude." Thus, according to Mondéjar,

far from being an uncertain period of time, the hegira provides the most certain and reliable system and is supported by the consent of so many different peoples. Father Moret and other authors have wasted their time in disputing over such an indisputable thing, and one upon which the

\footnotetext{
76 Ibid., 32-36.

77 Marqués de Mondéjar, Disertazión sobre el día y año en que comenzó la éjira o la hépocha de los árabes y de los mahometanos, BNE, Mss. 2288, 1v-2v.
} 
Africans and their neighbours would have instructed them if they had desired to inform themselves about the truth of the matter. ${ }^{78}$

This was a truly devastating conclusion: it was not the Arabs who differed over the hegira but mainly the Europeans, "for there is nothing more common among our European compilers than to place together opposed opinions, often without distinguishing between them or refuting any of them." ${ }^{\prime 9}$ To avoid the simple errors he had made, Father Moret need only have gone to ask the Africans, his neighbors, in order to discover the truth. ${ }^{80}$

Mondéjar's polemical disagreement with Joseph de Moret highlights several crucial points in the arguments used in this article: the technical problem of calculating chronological equivalences had by the seventeenth century become a more complex historiographical problem, which involved assessing the value of books written in Arabic, their use for writing the history of Spain, and the need to possess detailed knowledge of the history of Islam and its origins: a decisive step, then, in the process of historicizing Islam. This was, in addition, a polemical issue. Against the argument that Hispanic and Christian tradition could count on the most appropriate tools for providing the history of Spain with a reliable chronological structure, Mondéjar underlined the consistency of Arabic chronology and the need to incorporate other traditions. It is worth inquiring, at this point, about the singularity of Mondéjar's work and its meaning within seventeenth-century historiography.

\section{Spain and the Orient}

The Marquis de Mondéjar was one of the leading Spanish scholars of the seventeenth century. Mondéjar was the organizer of a tertulia in Madrid which discussed modern philosophical ideas, ${ }^{81}$ and his intellectual activity became one of the main routes of cultural transmission between the rest of Europe and Spain. This is evidenced not only by his specific epistolary contacts with European intellectuals but by the circulation of European books within his circle. Mercedes García-Arenal and I have already analyzed ${ }^{82}$ the European

\footnotetext{
78 Ibid., $2 \mathrm{v}-3 \mathrm{v}$.

79 Ibid., $4 \mathrm{v}$.

$80 \quad$ Ibid., 3v.

81 J. Pardo Tomás, El médico en la palestra. Diego Mateo Zapata (1664-1745) y la ciencia moderna en España (Salamanca, 2004), 133.

82 Mercedes García-Arenal and Fernando Rodríguez Mediano, The Orient in Spain, 307 and ff.
} 
dimension in Mondéjar's activity as an Orientalist, revealing several of its main aspects: firstly, his membership of a Spanish scholarly group which placed Oriental studies at the heart of its intellectual activity; in addition, the circulation within that group of a great deal of the European literature on Orientalist themes. In the extract quoted above, Mondéjar alludes to the important work of Ulugh Begh, whose tables were translated by John Greaves (London, 1650);83 this was just one example of how European Orientalist studies were used in Spain. To a large extent, the historiographical activity of this circle can be summarized as follows: the integration of the Andalusi and Arab past of the Iberian Peninsula represented a problem for a linear narrative of the history of Spain at a time of extraordinary preoccupation concerning antiquity and the subject of origins. One of the key ways to achieve such integration was by invoking the Orient, especially with reference to the Bible: an example of this is provided by the well-known extract in which Benito Arias Montano, under the influence of the medieval Sephardic exegetical tradition, identifies the toponym "Sepharad" in the book of Obadiah as Spain, and attempts to prove that the presence of Jews in Spain stretched back to antiquity. ${ }^{84}$ Mondéjar himself evoked the importance of this text, and its influence on later Spanish historiography, via Esteban de Garibay. ${ }^{85}$ Jews, Phoenicians, Arabs and pre-Islamic North Africans are discussed in Spanish historiography as proof of Spain's Oriental origins and, ultimately, of its relation with the sacred history of mankind.

In this way Mondéjar and friends belonging to his circle were thoroughly familiar with European Orientalist literature (Oriental languages were seen by them as "the key to true knowledge"), ${ }^{86}$ and such men were well aware of debates within the field through Mondéjar's relationship with men like Abraham Ecchellensis or Athanasius Kircher. The circulation of this kind of literature in Spain did not only mean that certain issues and common references were shared; it meant that the past of Spain (or in this case, the Muslim past of the Peninsula) was interpreted via such issues and such literature. Thus, the construction of a chronological apparatus of medieval Spanish history and the inclusion within it of the Muslim chronological system was inseparable from the development of a long-reaching cultural programme. The Obras

\footnotetext{
83 G.J. Toomer, Eastern Wisedome and Learning. The Study of Arabic in Seventeenth-Century England (Oxford-New York, 2007), "Greaves and Pococke in the East," 127 and ff.

84 Francisco Javier Perea, "Benito Arias Montano y la identificación de Sefarad: exégesis poligráfica de Abdías 20," Helmántica Hebraica vol. LI, no. 154 (Jan-Apr. 200o): 199-218.

85 Mondéjar, "Falsa introducción de los Judíos en España antes de venir los Cartagineses a ella," Noticia y juicio, 17 and ff.

86 BNE, Mss. 9881: Varias cartas de erudición, 225r.
} 
Chronológicas of the Marquis of Mondéjar were not published until the eighteenth century, by one of the leading Spanish Enlightenment scholars, Gregorio Mayáns, as part of an editorial project which aimed to bring to light the most outstanding works of seventeenth-century Spanish critical historiography. In the end, this project only succeeded in publishing Mondéjar's work and the Censura de historias fabulosas by Nicolás Antonio, a key figure of the pre-Enlightenment and of the field of bibliographical studies in Spain, for the collection planned by Mayáns was interrupted by pressure from the Inquisition. ${ }^{87}$ The figure of Mondéjar reveals a converging interest in chronology and Orientalist scholarship. The merging of these two interests eventually culminated in the conversion of the problem of the hegira into a historiographical problem, as the path shown by Juan de Mariana and others was gradually followed. Thanks to Mondéjar, Arabic sources and a knowledge of Islam manufactured their own space in the history of Spain; at the same time, a process of the historicization of Islam was culminated and should be taken into account as part of the general process of a common critical history of religions.

However, this point of view did not bring closure to the chronological problem in Mondéjar or other Spanish seventeenth-century historians. The question of the hegira forms part of a set of issues in which discussions of time articulated reflections about the origins (of both the homeland and the world) and the dividing lines between sacred and profane history. It should be remembered, as has been said above, that Mariana's Tractatus septem included another chronological work, on dating the death of Christ, which largely re-enacted the line presented in De annis arabum. The issue of determining the date of Christ's death is one of the most intensely studied problems in chronology, ${ }^{88}$ and it required the involvement of a number of crucial aspects in chronological discussions, such as the integration of sacred time in history, and also the need to draw a clear line between Judaism and Christianity that was based on the celebration of Easter. ${ }^{89}$ This led the first Christians to attempt to dissociate themselves from the Hebrew calendar in order to calculate the dates of move-

87 Rafael Benítez Sánchez-Blanco, "Gregorio Mayans y las láminas de plomo de Granada. Los límites de la crítica ilustrada," in ¿La historia inventada? Los libros plúmbeosy el legado sacromontano, ed. Manuel Barrios and Mercedes García-Arenal (Granada, 2008), 375-393.

88 Leo Depuydt, "The Date of the Death of Jesus of Nazareth," Journal of the American Oriental Society 122, no. 3 (2002): 466-480; Daniel J. Lasker, "The Date of the Death of Jesus: Further Reflections," Journal of the American Oriental Society 124, no. 1 (2004): 95-99.

89 See for example Diego de Otañez de Escalante, Repertorio perpetuo de los tiempos, muy copiosos conforme a la reformaçión y computaçión de N.B.P. Gregorio XIII (Alcalá de Henares, 1584), "Al lector." 
able feasts in a process which eventually gave rise to the Christian era. ${ }^{90}$ As has been shown, the long-lived attempt to determine the date of Christ's death and, therefore, the establishment of Easter, ran on throughout the Christian Middle Ages, becoming a key tool in the work of Scaliger and, therefore, in the emergence of historical chronology. ${ }^{91}$ This concern for establishing the date of Christ's death must be seen, then, within the perspective of a ritual time which established the precise dividing line between Christianity and Judaism. ${ }^{92}$ In Spain, opinions about this date could sometimes go beyond the limits of scholarly debate: Mariana's own view on the date of Christ's death was criticized by one of his detractors, Pedro Mantuano, who considered it "opposed to holy scripture and the evangelists." ${ }^{93}$ Some years later, in 1622, the Spanish Inquisition discussed the possible prohibition of the Conclusiones cronológicas of Father Alonso Maldonado. Some members argued that to challenge the date traditionally accepted by the Church, though not an issue of dogma, could constitute a problem if it were done in the common tongue, "because of the danger of disturbing the mood of the unlettered faithful already instructed by the church about those doubtful questions that arise from Scripture because in so doing one might undermine the satisfaction and good faith of the people." What was more, there was a danger that "the ambassadors from foreign kingdoms and England might send them [Maldonado's conclusions] back to their kingdoms and republics, and in them it would be seen that the most common and widely held beliefs of the saints and the Church were criticized through the use of deceit and error." ${ }^{\text {94 }}$ Furthermore, tension between the Christian and Hebrew calendars was constantly refueled in a society obsessed by purity of blood and the possible existence of Crypto-Jews; thus, one of the most widely

9o Alden A. Mosshammer, The Easter Computus and the Origins of the Christian Era, (OxfordNew York, 2008). See also the review of this book by Timothy D. Barnes in Journal of Ecclesiastical History 60 (2009): 545-547.

91 C. Philipp E. Nothaft, Dating the Passion: The Life of Jesus and the Emergence of Scientific Chronology (200-160o) (Leiden-Boston, 2012). Roger T. Beckwith, Calendar \& Chronology, Jewish \& Christian. Biblical, Intertestamental \& Patristic Studies (Leiden-New York-Köln, 1996), 276 and ff.

92 An example of this polemic concerning the period of Jesus's life, referring to Abraham Ben Daud, can be found in Joanna Weinberg, "Invention and Convention: Jewish and Christian Critique of the Jewish Fixed Calendar," Jewish History 14, no. 3 (2000): 317-330, 324. "Plegue a Dios que este error sea del entendimiento y no de otra cosa." Ángel González Palencia, "Polémica entre Pedro Mantuano y Tomás Tamayo de Vargas, con motivo de la "Historia" del Padre Mariana," Boletín de la Real Academia de la Historia 84 (1924): 331-351, 335-336. 
read chronological works of the period, the Chronographia of Génébrard, was systematically censored in Spain because, although Génébrard was an authority in the Catholic world, and was recognized as such even by Protestants, the annex contained the so-called Historica Cabbala, a Latin translation of the Sefer ha-qabbala by Abraham ben Daud. ${ }^{95}$ This Latin translation, according to Inquisition assessors, would provide conversos, "whose blood still boils, the chance to learn new prayers, rites, ceremonies, doctrines, funeral services, symbols and prayers taken from the books of Talmud and from other rabbis which they would be able to read in Latin and understand many of them, whereas in the original Hebrew they would understand few or none."96

It is here that one of the greatest implications of chronological calculations becomes clear: in reality, the calculation of equivalence between lunar and solar cycles was a huge simplification of another greater problem, which was that of the adaptation of complex lunisolar calendars which had to contain a religious component but also had to be explained within a coherent history of all mankind. The simple continuity which some authors propose between the Hebrew and Muslim calendars would seem to reflect part of this problem, in which the connection between the lunar and solar system (or rather, the construction of a coherent lunisolar calendar) is also in many ways a point of connection between Hebrew and Christian chronology and, for the same reason, an important element in the very possibility of writing sacred history. The most important Spanish biblical scholar, Benito Arias Montano, was a contemporary of Juan de Mariana who was able to construct around the edition of the Polyglot Bible of Antwerp a vast project of integration of the history of Spain and mankind in the biblical world, in its geography, language and etymology, in a temporality which points to the logic of salvation. In this context it is worth remembering, for example, his proposal to understand the relationship between time and eternity through the difference between the Hebrew terms Gholam ("century or orb, and centre of some thing"), Dor ("period or duration") and Tholedah ("history or description").97 The problematical

95 For the discrepancies between the Septuagint and the Hebrew Bible in medieval Judaism, and specifically in the case of Abraham ben Daud, see "The Rabbinic Legend of the Septuagint in Abraham ibn Daud's Writings," in The Multiple Meaning of Scripture: The Role of Exegesis in Early-Christian and Medieval Culture, ed. Ineke van 't Spijker (BostonLeiden, 2009), 41-59.

96 AHN, Inquisición, 4436/8.

97 B. Arias Montano, Historia de la naturaleza. Primera parte del Cuerpo de la Obra Magna, coord. ed. Fernando Navarro Antolín (Huelva, 2003), 269-272. The moment of creation is also the moment at which time was established, as a way of measuring the duration of things created: a "day" which existed even before the sun, light and darkness. Letter from 
connection between Hebraism and Christianity is also reflected in chronology. Mondéjar himself wrote a short treatise to demonstrate what he called the "Inconsistency of rabbinical and modern writings, uncertain and variable, origin and antiquity of their computations, what they understand of Christ and the age in which he flourished. Diversity of calculating the years of the creation and since when they have used this reckoning." ${ }^{\prime 98}$ As the title suggests, the work sets out to show the inconsistencies of rabbinical writings on chronology, especially in their coverage of the chronology of the creation of the world and in particular the life of Christ. ${ }^{99}$ Mondéjar argued that the pretension that Hebrew computation could be traced back to the period of Moses was false, since he did not know of any Jewish writer who had written on the subject before the life of Christ. Above all, the worst thing was the attempt to put back the period of the life of Christ, "anticipated maliciously by the modern rabbis to deny that the destruction of the Temple could have been a punishment for his innocent death, as the Christians pointed out to them."100 Mondéjar's antiJudaism was reflected, in this case, in the polemical aspect of the chronology of the life of Christ as a barrier between the Christian and Hebrew calendars. What was more, the idea that the Jews had altered the chronology of the scriptures, out of malice or ignorance, is an old chestnut from anti-Jewish polemic which now became part of the arsenal of critical historians. In the words of the priest and historian Jacinto Segura $(+1751)$, "this ignorance [of chronology]

Pedro de Valencia to José de Sigüenza, Zafra, May 7, 1603, in Pedro de Valencia, Epistolario, ed. Francisco Javier Fuente Fernández and Juan Francisco Domínguez Domínguez (Madrid, 2012), 147.

98 Marqués de Mondéjar, [Contestación a los reparos hechos a las Disertaciones eclesiásticas], 2 vols., BNE, Mss. 5557-5558, $54 \mathrm{r}$ and ff.

99 In the field of exegesis, the subject of biblical chronology and its inconsistencies was widely studied for a long period. For example, the Sevillian Jesuit Luis del Alcázar (+1631), a celebrated commentator on the Apocalypse, highlighted the chronological inconsistencies of the Bible by alluding to the different systems which may have been known to St. John (Hebrew, Greek, Julian etc.), but also to the "mystical meaning" of biblical years. This mystical meaning (one of the meanings of the Bible identified by exegesis) allowed him to venture his own interpretation of the apocalyptic text. Luis del Alcázar (Ludovici ab Alcasar), Vestigatio arcani sensus in Apocalypsi (Antuerpiae, 1619), 525-527. Thus, "five months" could mean "five monarchies" (Ibid., 487-488). See for example Eric Lawee, "Isaac Abarbanel: From Medieval to Renaissance Jewish Biblical Scholarship," in Hebrew Bible / Old Testament. The History of Its Interpretation._II: From the Renaissance to the Enlightenment, ed. Magne Sæbø, (Götiengen, 2008), 211.

100 Ibid., 59v-6or. 
made the Hebrew writers invent fictions in various parts of Holy Scripture, as a way of bringing order to the timing of events."101

Mondéjar's interest in the Bible and Hebrew chronology was therefore situated at a crucial point in his historiographical project, the point at which the history of Spain was to be integrated within the sacred history of mankind. It thus becomes possible to understand, for example, that his concern over determining the date of the Arab conquest of Spain and, in general, the origin of Muslim dating systems, eventually became an interest in the origin of mankind. It was in this spirit that he sponsored the Spanish translation of a manuscript in his possession, the Rawdat al-manäzir by Ibn al-Shihnna, a work containing a history of the world from the time of its first origins. As was explained by its translator, the Sevillian scholar Juan Durán Torres, this work was "a History found in the possession of Don Gaspar Ibañez by Abu Walid Ben Shacenas and is a general chronicle with great exactitude, in the ancient period and that of the first monarchies, as in the latest period of Sarracen history"102 The expression "first monarchies" is an allusion to the origins of mankind and the chronology of the ancient dynasties, especially those of Egypt. Another contemporary document (probably a work by Mondéjar) referring to the same chronicle by Ibn al-Shihna or perhaps another Oriental chronicle, talks of the unreliability of a superstitious Muslim author who, in dealing with the subject of the Egyptian dynasties, had believed the "fantasies with which the Egyptians entangled their origins," adding references to non-existent princes and other events which made their chronology go far beyond that of the Christians. ${ }^{103}$ This was a serious problem which had already been highlighted by Benito Arias Montano who, in a discussion of Moses's upbringing in Egypt, had written that "the Egyptians boast that they are the first and most ancient of men and claim that the world has no beginning or that it existed much before the time when it really did."104

Mondéjar urged and sponsored the translation of Oriental chronicles not only because they might clarify the chronology of al-Andalus or medieval

101 Jacinto Segura, Norte crítico con las reglas más ciertas para la discreción en la historia (Valencia, 1737), 28.

102 Letter from Juan Durán de Torres to Nicolás Antonio, May 26, 166o; Nicolás Antonio, Censura de historias fabulosas, 671-672. See Mercedes García-Arenal and F. Rodríguez Mediano, The Orient in Spain, 392, n. 31.

103 Varias cartas de erudición, BNE, mss. 9881, f. 255, Mercedes García-Arenal and F. Rodríguez Mediano, The Orient in Spain, 414.

104 Benito Arias Montano, Historia de la naturaleza. Primera parte del Cuerpo de la Obra Magna, coord. ed. de Fernando Navarro Antolín, (Huelva, 2003), 251. 
Spain but above all because they contained new information on the history of Egypt, its ancient dynasties and their chronologies. Of course, such chronologies came into conflict with those of the Bible. That this issue was a delicate one for Mondéjar is shown by one of his treatises, in which he tried to defend the idea that Moses had been the very first writer in history: this treatise sought to argue against the opinion of Agostino Mascardi but had the more general aim of revealing to all "the disillusion and fiction of the superstitious Gentiles and the wicked domestic enemies of the Church."105 To bring this off through the use of chronological arguments, he tried to show that Moses was the most ancient of all writers, paying particular attention to the calculations of Denis Pétau, and also using classical, Hebrew and Latin sources. ${ }^{106}$ Chronology was no longer a tool for writing the history of Spain but embodied the very possibility of the existence of sacred history. In this polemic, what became radically clear was the tension mentioned at the start of this article surrounding Esteban de Garibay and his decision to open his history of Spain with Adam: the project of writing a critical history had reached a limit by redefining the history of the world.

\section{Conclusion}

As I have said, Spanish Enlightenment historians recognized their intellectual affinities with the Marquis of Mondéjar and his chronological works, which were not published until they were edited by Mayáns i Siscar in 1744. In the eighteenth century, the Real Academia de la Historia sponsored a number of relevant projects such as the attempt to carry out an official chronological treatise or Tratado de Cronología de España. One crucial figure in the history of the Academia, and in Spanish eighteenth-century politics, Pedro Rodríguez de Campomanes $(+1802)$, played an active role in these projects, as did Miguel Casiri, the Maronite monk who arrived in Spain in 1747 and became professor of Arabic to Campomanes. Casiri was also to compile a monumental catalogue of the Arabic manuscripts held at El Escorial, the Bibliotheca arabico-hispana escurialensis, in a clear sign that the project of Enlightenment history, sponsored by official institutions, was by now able to accept the realization of a documental and numismatic Arabic corpus of Spain, and its key role in

\footnotetext{
105 Marqués de Mondéjar, "Razón y asunto de esta obra: Moysén, universalmente celebrado por primer escritor. Opónese Mascardo a esta verdad, impugnando el sentir de todos los padres de la Iglesia," BNE, Mss. 5557, $227 \mathrm{v}$.

106 Ibid., 283v.
} 
chronology, and to take into account the efforts made by sixteenth- and seventeenth-century critical historians. However, recognition of the usefulness of Arabic sources and Muslim chronology did not imply that a solution to the technical problem of date conversion had been achieved. Spanish historians continued to see the issue as unresolved, returning again and again to the bibliography on the subject and reviewing the main achievements of the works of Mariana and Mondéjar by discussing their successes and errors. Accepting the need to consult Arabic sources to clarify chronological issues often did nothing more than complicate the technical issues: apart from errors and vaguenesses, it was necessary to take into account the different ways of referring to time, parts of the day or canonical prayers, the simultaneous use of lunar and solar calendars, etc. The works of Juan Francisco de Masdeu $(+1817)^{107}$ or Enrique Flórez $(+1773)^{108}$ show how tortuously difficult this process could be. In the early nineteenth century, Martín Benedito was still able to complain about the absence of a reliable tool for the conversion of dates, a state of affairs which he regarded as reprehensible among foreign historians but even worse in those of Spain, "for they had more opportunity, some to hear and deal with the Arabs themselves, and others to handle and encounter their writings, than those of other nations." ${ }^{109}$ It would be pointless to list here the number of Spanish and European historians who dealt with this subject over the course of the nineteenth and twentieth centuries. The instrumental nature of all these works provides evidence of the eventual transformation of a historiographical problem which had unraveled in previous centuries. The disagreements between the astronomical and historiographical traditions were transformed as writers of the history of Spain began to address the problem of the Arabic sources and also the demands of new technical tools such as chronology. However, this historiographical issue uncovered new problems, as the dividing line between the Hebrew and Christian calendars turned out to be the line between Judaism and Christianity. In the Spain of the sixteenth and seventeenth centuries, the issue of the "judeo-conversos" was a highly important one, as was, to the same extent, the historical obsession concerning the presence of Jews in ancient Spanish history; this was an issue naturalized by Arias Montano, within a global

\footnotetext{
107 Juan Francisco de Masdeu, Historia crítica de España y de la cultura española. t. XIV, l. III.España árabe: ilustraciones cronológicas, históricas y críticas (Madrid, 1794).

108 Enrique Flórez, España sagrada. II.- Cronología de la España antigua (Madrid, 200o), 239-301.

109 Martín Benedito, Arte de verificar las fechas arábigas o método seguro de reducir los días, meses y años de la cuenta lunar mahometana a días, meses y años civiles, christianos, BNE, Mss. 1707 , 11 r.
} 
attempt to link the past of Spain to the biblical and Oriental world. To discuss the integration of the Muslim calendar in narrations of the history of Spain was, firstly, to attempt to bring about the impossible integration of al-Andalus in Spain, but at the same time it was another way of contemplating the obsessive problem of Spain's Oriental past. As I have tried to show, this was a problem which, in Spain, was largely tackled through the circulation of European books on chronological and Orientalist subjects. The relationship between the origins of the world and the origins of Spain became explicit, for example, in the use of Oriental books which could throw light on Egyptian chronologies. It was at this point that a limitation to seventeenth-century Spanish critical history appeared: that which was represented by the Bible and the problems of its chronology and historical authority. 